\title{
Organizational and Methodological Guidelines for Training Education Managers to Implement the Strategy of Corporate Social Responsibility
}

\author{
Olena Bila \\ Department of Pedagogy, \\ Preschool, Elementary and \\ Special Education \\ Izmail State University of \\ Humanities \\ Izmail, Ukraine \\ http://orcid.org/0000-0002-3143- \\ $718 \mathrm{X}$
}

\author{
Irina Gontareva \\ Department of Marketing, \\ Management and \\ Entrepreneurship \\ V.N. Karazin Kharkiv National \\ University \\ Kharkiv, Ukraine \\ http://orcid.org/0000-0002-2242- \\ $378 \mathrm{X}$
}

\author{
Vitalina Babenko \\ Department of International \\ E-Commerce and \\ Hotel\&Restaurant Business \\ V.N. Karazin Kharkiv National \\ University \\ Kharkiv, Ukraine \\ http://orcid.org/0000-0002-4816- \\ 4579
}

\author{
Olena Kovalenko \\ Scientific Research Institute of \\ Forensic Sciences \\ Dnepr, Ukraine \\ http://orcid.org/0000-0002-6802- \\ 7213
}

\author{
Nataliia Gliebova \\ Department of Management and \\ Administration \\ Kharkiv National University of \\ Pharmacy \\ Kharkiv, Ukraine, \\ http://orcid.org/0000-0002-9908-
}

3867

Received: December 1, 2019. Revised: October 1, 2020. Accepted: October 19, 2020. Published: October 21, 2020.

\begin{abstract}
The article highlights the theoretical bases for professional training of future education managers to effectively implement the strategy of corporate social responsibility in educational institutions. There outlined prospects for introducing a cluster of elective courses for masters at faculties of education oriented towards acquiring knowledge on design tools and successfully applying strategies of corporate social responsibility in institutions of pre-school, primary, out-of-school, and alternative education. The authors propose an algorithm for a phased construction of a practice-oriented process of training education masters, which is developed based on their previous theoretical works. Its structure includes a set of individual research tasks aimed to create promising corporate social responsibility projects in institutions of pre-school, primary, special, out-of-school, and alternative education of various forms of ownership
\end{abstract}

Keywords - Educational institution, professional training of education managers, corporate social responsibility, entrepreneurship, elective course, methodological service

\section{INTRODUCTION}

The 2016 World Development Report: Digital Dividends presented by World Bank Group [32] emphasizes the rapid growth of social inequality in the modern digital economy. In this regard, it is important to consider the problem of defining a new paradigm for university training of education managers and teaching staff of institutions of pre-school, primary, special, outof-school, and alternative education in part of their readiness to implement the strategy of corporate social responsibility.

Especially it concerns the system of training education masters in terms of forming their economic competence, focusing on productive mastering of modern techniques for managing educational institutions and mechanisms of financial and economic activities.

Modern studies interpret the concept "social responsibility" differently. However, in the opinion of most experts, the reference definition is the one proposed in the International Standard ISO 26000: Guide to Social Responsibility (2010). The document states that social responsibility is the responsibility of an organization for the impact of its decisions and activities on society and the environment through transparent and ethical behavior, which is expressed in such aspects as: contributing to sustainable development, including health and welfare of society; taking into account the expectations of stakeholders; compliance with applicable law; consistency with international norms of behavior; integration throughout the organization [16].

In view of this, it is absolutely reasonable to consider the opinion of a number of scholars stating that teaching social responsibility is one of the main functions of a higher education institution (Burlayenko, T. I. (2011) [7], Donia, M. B. L., \& Tetrault Sirsly C. A. (2016) [10], Kotler, P., \& Lee, N. (2004) [18], Perfilieva, O. V. (2011) [24], Porter, M., \& Kramer, M. (2006) [26]).

It should be noted that the analytical review of priorities of the education policy in the higher education system of the USA, Canada, Italy, Finland, and Norway (members of the Organization for Economic Cooperation and Development (OECD) [20] for the first time specified the functions to be implemented by higher education institutions which act based on the principle of socially responsible institutions. According to the experts, the functions include: reproduction of social intelligence (rendering educational services aimed directly at serving a person and their free development; training highly qualified staff (the elite of society), which in turn will contribute 
to scientific, technical and socio-economic progress of the country; formation of the labor market (new knowledge produced in an educational institution has a direct impact on the labor market and encourages rethinking the significance of certain skills, which results in changing quantitative and qualitative requirements for labor resources); development of culture and norms of behavior, presence and observance of which largely determines the psychological climate in the system of higher education and its market capitalization; stabilization of social relations (an educational institution is an active participant in social interaction with stakeholders and numerous representatives of the social environment of the region).

In the business community, the concept "corporate social responsibility" is most applicable. Today it is widely used in sociology, business, situational management, and marketing. In line with our scientific research, it is important to consider the concept in the interdisciplinary, psychological and educational context.

As rightly pointed out by the founder of the theory of business management and marketing in the era of turmoil Kotler, P., \& Lee, N. (2004), corporate social responsibility is the concept of the functioning of a single organization (corporation) reflecting its specific obligations to customers, employees, shareholders, environmental organizations [18]. Moreover, such obligations should be viewed not just as a set of formal principles based on which a company builds its business processes. According to Kotler, P., \& Caslione, J. A. (2009), this is a philosophy on entrepreneurial and social activity which organizations adhere to in order to ensure their development, a decent level of social life of people and society as a whole and preserve the environment for future generations [17].

In particular, this is about the synthesis of its core elements, namely: cultivation and enhancement of companies' image and business reputation; corporate development, which implies implementation of restructuring and organizational changes with participation of representatives of the companies' top management, their staff, and public organizations; corporate ethics; environmental policies and use of natural resources; staff policy; health, safety, and labor protection; observance of human rights; interaction with local authorities, government institutions, and public organizations to solve common social problems; social aspects of communication with the companies' suppliers and buyers of their products and services; PR support of the mentioned areas [21].

Among various reasons which encourage companies to implement the concept of corporate social responsibility, the most important, according to researchers Dmitriev, V. A. (2011), Porter, M., \& Kramer, M. (2006) are: globalization and associated with it intensification of competition; growing size and influence of companies; enhancement of mechanisms of government regulation; the war for talent - competition of companies for staff; increase in civic engagement; increasing role of intangible assets (reputation and brands) [9;26].

Researches on the practice of corporate social responsibility confirm the fact that one of the topical directions in the implementation of a company's social policy is human resource management, both internal (staff) and external (local community), which has a significant impact on the achievement of business goals [6]. Accordingly, each of these areas is associated with quality of education, training managers able to harmoniously combine economic, environmental, and social activities.

It should be emphasized that over the past decade quite a lot of researches have been carried out to determine the chances of organizations' obtaining benefits from social activities. After conducting a large-scale research in this direction, scientists at the Harvard Business School found that the enterprises which use social programs in their activities are superior in all essential indicators to those which do not use these programs. In terms of return on assets ratio, $\$ 1$, invested in social activities in 1993, brought $\$ 7$ by 2010 . While $\$ 1$ invested in a company without a social program brought only $\$ 4$. These data, as noted by Belyaeva, I. Yu., \& Eskindarov, M. A. (2008), are direct evidence that corporate social responsibility is a factor which has a significant impact on implementing a strategy for sustainable functioning and development of organizations engaged in different activities [2].

Along with medical care, social security, and formation of a comfortable social infrastructure, foreign companies are actively involved in the development of the education sector as one of the areas of social investment within their corporate social responsibility strategy [6]. Thus, Panova, A. Yu. (2017) emphasizes that, speaking about the current period of 20152020, large Russian industrial companies located in the regions of the country consider supporting professional education in close cooperation with government authorities and national educational organizations the most important direction [23].

In the past, as experts on US education Robinson, K., \& Aronica, L. (2016) stress, for a whole century, the financing of mass education in developed countries of the world was carried out by taxpayers. However, the current administrations of many states encourage the attraction of investment in education by private corporations and entrepreneurs [27; 28]. They get involved in the process based on increasing the scale of commercialization of educational services and discussing the most favorable conditions with the top management, teaching staff, and parents. Moreover, the range of such services can vary from selling their products and services to educational institutions to establishing their own schools and alternative institutions with the receipt of profit from them.

Thus, there is a need to systematize the priorities and mechanisms for implementing the strategy of corporate social responsibility in preschool, primary, out-of-school, and alternative educationinstitutions.

\section{PRIORITY DIRECTIONS FOR THE IMPLEMENTATION OF CORPORATE SOCIAL RESPONSIBILITY STRATEGY IN EDUCATIONAL INSTITUTIONS}

Educational institutions of various types in Eastern Europe are functioning under difficult internal and external conditions. First of all, we are talking about the transition of a number of them to autonomy, changes in the regulatory framework, competition, introduction of new forms of remuneration, changes in the preferences of children and parents as consumers of educational services, the need of the institutions for 
cultivating image and reputation, financial stability, flexibility, dynamism and adaptability, attraction of children and young people to basic and additional educational services, involvement of young and highly qualified staff, etc.

In this regard, the social mission of an educational institution is transformed from a monopolist to a coordinator of education, socialization and corporate interaction with various target audiences; there is a growing need to choose and implement their own vector of corporate social responsibility, organizational and managerial innovations, most of which are associated with educational marketing, creative management, "management of the process of positioning an educational institution in the educational market" [30].

To implement the corporate social responsibility strategy in a particular educational institution, managers need, first, to determine the areas that currently should be paid increased attention as a resource for new opportunities to successfully solve current social and environmental problems; secondly, to analyze the expectations of representatives of the parties concerned (teaching staff, pupils and student youth, parents, business partners, government officials, experts, investors) as to the areas of corporate social responsibility the institution should be oriented to with consideration to its specifics.

Theoretical analysis of various areas of implementing the strategy of corporate social responsibility in the field of entrepreneurship and education [8-11; 13-15], has allowed focusing our research interest on such important for educational institutions areas as: responsible practices in relation to teaching staff; environmental protection; fair business practices; responsible practices in relation to consumers of educational services; community development; charity and volunteering. Let us specify what socially responsible practices can be applied in an educational institution to achieve positive changes in the above areas (Tbl.1).

TABLE I. MAIN AREAS AND PRACTICES OF IMPLEMENTING CORPORATE SOCIAL RESPONSIBILITY STRATEGIES IN EDUCATIONAL INSTITUTIONS [BASED ON $8-10,14]$

\begin{tabular}{|c|l|}
\hline Areas & \multicolumn{1}{|c|}{ Socially responsible practices applied } \\
\hline $\begin{array}{c}\text { Responsible } \\
\text { practices in } \\
\text { relation to } \\
\text { teaching staff }\end{array}$ & $\begin{array}{l}\text { - Application of transparent procedures for } \\
\text { employment (or dismissal), certification, promotion, } \\
\text { pay rise for teaching staff. } \\
\text { - Creation of a safe working environment and ensuring } \\
\text { teacher safety. } \\
\text { - Application of a wide range of additional programs } \\
\text { for the purpose of training and improving professional } \\
\text { skills of teaching staff and education managers. } \\
\text { - Provision of attractive social benefits and guarantees } \\
\text { (medical, pension, housing programs, programs for } \\
\text { young professionals, sanatorium-resort care, etc.). } \\
\text { - Observance of the rights of teachers to freedom of } \\
\text { association in professional teams and collective } \\
\text { bargaining. } \\
\text { - Non-discrimination and creation of equal } \\
\text { opportunities for all employees regardless of race, } \\
\text { gender, religion, national or social origin, political } \\
\text { preferences, age, etc. } \\
\text { - Cultivation of corporate culture and creation of } \\
\text { intangible incentives for teaching staff. } \\
\text { - Maintenance of a balance between the functional } \\
\text { authority and the personal life of teaching staff. }\end{array}$ \\
\hline
\end{tabular}

\begin{tabular}{|c|c|}
\hline $\begin{array}{l}\text { Environmental } \\
\text { protection }\end{array}$ & $\begin{array}{l}\text { - Minimization of any pollution (within the territory of } \\
\text { an educational institution and in its neighborhood, } \\
\text { competent waste disposal, etc.). } \\
\text { - Efficient use of energy resources, water, heating } \\
\text { within an educational institution, implementation of } \\
\text { innovative technologies to ensure efficient energy } \\
\text { consumption. } \\
\text { - Preservation and expansion of natural ecosystems } \\
\text { within the territory of an educational institution, } \\
\text { introduction of diversity in the eco-design of the } \\
\text { interior of an educational institution. } \\
\text { - Consideration for environmental factors in } \\
\text { organizing the work of an educational institution } \\
\text { (saving paper, energy, water; optimal reduction of } \\
\text { business trips by replacing them with video } \\
\text { conferencing; raising the level of environmental } \\
\text { awareness of the teaching staff, parents, children and } \\
\text { youth, etc.). }\end{array}$ \\
\hline $\begin{array}{c}\text { Fair } \\
\text { business } \\
\text { practices }\end{array}$ & $\begin{array}{l}\text { - Compliance with the principles of fair competition } \\
\text { within a particular educational institution, among } \\
\text { several institutions, etc. } \\
\text { - Combatting corruption. } \\
\text { - Creation of additional, including tangible, incentives } \\
\text { to integrate the principles of corporate social } \\
\text { responsibility in activities of business partners. } \\
\text { - Promotion of the principles of corporate social } \\
\text { responsibility in the educational community (holding } \\
\text { conferences, training events, preparing thematic } \\
\text { publications, etc.). } \\
\text { - Provision of support for public processes for the } \\
\text { development and implementation of national strategies } \\
\text { aimed at the benefit of the educational community. }\end{array}$ \\
\hline $\begin{array}{l}\text { Responsible } \\
\text { practices in } \\
\text { relation to } \\
\text { consumers of } \\
\text { educational } \\
\text { services }\end{array}$ & $\begin{array}{l}\text { - Provision of quality educational services which do } \\
\text { not pose a threat to social, psychological and physical } \\
\text { health and life of all subjects of training and education. } \\
\text { - Conscientious informing all consumers about the } \\
\text { content and quality of educational services. } \\
\text { - Existence of procedures for compensation for } \\
\text { damage in case of rendering educational services of } \\
\text { low and unsatisfactory quality. } \\
\text { - Provision of the confidentiality of personal data of } \\
\text { participants in the educational process. } \\
\text { Introduction and promotion of alternative } \\
\text { information segments in the modern educational } \\
\text { world, educational innovations and new information } \\
\text { technologies in education. }\end{array}$ \\
\hline $\begin{array}{c}\text { Development of } \\
\text { local } \\
\text { educational } \\
\text { communities }\end{array}$ & $\begin{array}{l}\text { - Creation of new jobs and improvement of the } \\
\text { professional level of teachers in the region. } \\
\text { - Provision of support for local educational } \\
\text { communities. } \\
\text { - Investments in solving regional problems in the field } \\
\text { of education and culture, expanding educational } \\
\text { activities (programs, projects) in the regions, } \\
\text { promoting innovative technologies and implementing } \\
\text { local initiatives in the field of education. } \\
\text { - Observance of the right of the indigenous population } \\
\text { and small peoples to a high-quality education. }\end{array}$ \\
\hline $\begin{array}{l}\text { Charity and } \\
\text { volunteering }\end{array}$ & $\begin{array}{l}\text { - Implementation of and support for charitable } \\
\text { educational programs and projects aimed at different } \\
\text { target audiences, creating a favorable social and } \\
\text { cultural environment. } \\
\text { - Formation of a system to stimulate teaching staff, } \\
\text { pupils, students, and parents to participate in volunteer } \\
\text { activities. }\end{array}$ \\
\hline
\end{tabular}

It should be emphasized that for the management team of an educational institution it is important to concentrate efforts on the most significant topics and areas of corporate social responsibility. Some areas listed in Table 1 may be equally 
important for all organizations (e.g., responsible behavior in relation to teaching staff), some - specific or irrelevant.

At the same time, it is important not only to identify the main areas for implementing the strategy of corporate social responsibility in a particular educational institution but also to ensure systematic interaction of managers with key parties concerned; planning algorithms, stages of the implementation and monitoring of effectiveness of social and educational programs (projects); assessing the effectiveness of social investments, etc. [10].

As B. Shahnazaryan emphasizes, in the situation of successful implementation of any area of the corporate social responsibility strategy, it is advisable to rely on recommendations for further improvement of the strategy in an educational institution, namely:

considering corporate social responsibility as an integral system which not only makes it possible to effectively solve social problems but also provides additional competitive advantages;

relying on the strengthening of relations with external stakeholders, which allows an educational institution to ensure sustainable development;

timely popularizing social practices, which in turn will provide for creating a positive image of an educational institution;

positioning an institution as a serious player having longterm prospects;

using assistance of various companies to ensure international exchange of experience in the field of corporate social responsibility;

keeping balance between the desire for profitability and the moral requirements of society;

introducing innovative projects aimed at solving challenges in the country and in the world as a whole;

based on international experience, introducing a nationally accepted methodology for assessing corporate social responsibility together with other companies and experts [29].

\section{THE PHENOMENON OF ENTREPRENEURIAL COMPETENCE OF FUTURE EDUCATION MANAGERS (THE VECTOR OF IMPLEMENTING THE CORPORATE SOCIAL RESPONSIBILITY} STRATEGY)

It is obvious that the degree of successful implementation of the above areas of corporate social responsibility strategy naturally depends on the competence of education managers in the field of strategic and situational management, enhancement of the entrepreneurial component of management activities.

In scientific sources, the category "entrepreneurial attitude" is considered from the position of the key (super subject) competency of an individual. The "entrepreneurial attitude of a subject" is understood as the ability of a subject to generate productive ideas, put forward perspective initiatives for their implementation to improve their own social status and welfare as well as to develop society and the country.
In view of the above definition, it is appropriate to focus on the modern classification of the psychological components of the competency "entrepreneurial attitude" which are essential for an education manager, namely: a manager's possession of the internal locus of control (the tendency to associate results obtained with the internal traits of the personality and not the influence of external circumstances); tolerance of an education manager towards uncertainty (a personality trait which allows confidently withstanding a crisis caused by uncertain life circumstances); the need for achievements and productive results (as opposed to the need to avoid failures; preferential focus on the final result and not on the process); assertiveness (the ability of a person to defend their point of view, without violating moral rights of another person; the ability to respond optimally to criticism and to decisively say "no" to themselves and others, if circumstances so require); resilience (the ability of a person or a group of people to overcome serious problems and continue developing; viability, lifelong learning); the ability to risk (the need to make decisions aimed at achieving success but do not guarantee it due to uncertainty of the situation as well as variability of the economic situation).

Along with the availability of the necessary starting resources (tangible, land, labor, financial ones), efficient education managers as subjects of entrepreneurial activity should acquire the following systemic knowledge concerning: regulatory framework for financial, economic, and entrepreneurial activities, staff management; theoretical bases of economics, educational management, marketing, financial and business activities; business organization mechanisms. The main entrepreneurial skills of an education manager, first of all, include the following abilities: to give a reasonable assessment of entrepreneurial activity; find non-standard solutions to problems; identify and evaluate new business ideas; assess the external and internal conditions of entrepreneurial activity; conduct negotiations and draw up contracts; make a profit, etc.

It should also be emphasized that it is self-actualized managers who in the future can achieve a higher level of entrepreneurial activity. These are strategic managers. They have a high level of self-realization; the ability to create values that transform not only education but also other areas of activity; the potential to establish their own unique educational institution as well as any other one (including partner organizations). Having meta-professional knowledge, skills and abilities at the level of business intuition, they occupy the leading positions of analytical experts in management activities.

Thus, considering the above described characteristics of selfactualized managers and strategic managers, it becomes obvious that they are the ones who can become key figures in successfully achieving the goals related to the implementation of areas of the corporate social responsibility strategy in an educational institution.

\section{THE COMPENSATORY ROLE OF THE AUTHORS' PROGRAMS OF ELECTIVE COURSES (THE CONTEXT OF PREPARING MASTERS FOR DESIGNING CORPORATE SOCIAL RESPONSIBILITY STRATEGIES IN EDUCATIONAL INSTITUTIONS)}

In order to provide organizational and methodological support for the educational process of preparing future managers for designing corporate social responsibility strategies in 
educational institutions, we have elaborated a certified program "Social and instructional design in preschool and primary education institutions" [3] for graduate students, which includes the following copyright programs of elective courses: Methodological bases of social and instructional design, Social and instructional design in pre-school and primary education institutions, Design technologies in out-of-school education facilities, Basics of forming a project team of experts in the field of socionomics, Management of social and educational projects in educational institutions, Professional training of teachers of preschool and primary education institutions for project activities [4], Designing innovative educational systems in preschool and primary education institutions [5].

The development of the authors' programs was based on the following methodological approaches: axiological (with the focus on meeting current and identifying potential educational needs of future managers in designing corporate social responsibility strategies), variable (implying the provision of an optimal set of methodological guidelines for meeting diverse educational needs of future managers and ensuring the right to choose the optimal set of areas for implementing the corporate social responsibility strategy in educational institutions (Tbl.1), andragogical (ensuring effectiveness of continuous interaction among subjects in the course of educational process, including at the stage of postgraduate education), technological (implying the construction of the process of providing the methodological support for future education managers using advanced technologies), stakeholder approach, and systems one (as the integration of all previously listed approaches).

It should be noted that choosing a stakeholder approach for academic training of future managers is determined by results obtained in analyzing the development of foreign higher education systems, which justify the need to cultivate the ethics of corporate social responsibility of higher education institutions using the principle of business institutions. In view of this, the question of the need for a broader interpretation of the concept "social mission of a university" arises. This concept today is the basis for determining social responsibility of higher education institutions as a key priority of the national education policy in some foreign countries, in particular in Finland [20].

The authors' certified program for future Masters of Education is built on three subject and competency focuses:

theoretical knowledge in the field of methodology of social and instructional design in institutions of preschool, elementary, out-of-school, and alternative education; algorithms for the development and implementation of high-tech educational services;

managerial (administrative) competencies, which allow working in the area of development management; application of innovative practices under market conditions; adoption of nonstandard managerial decisions on implementing the strategy of corporate social responsibility, team building, and managing social and educational projects; introduction of organizational and procedural aspects related to preparing various subjects of the interpersonal professional environment (representatives of teaching staff and associations; project dyads and teams; multidisciplinary groups, groups of investors and stakeholders, members of volunteer, sponsorship and charitable organizations, etc.) for a productive collaboration in project activities;

basics of cultural entrepreneurship, which allow future masters introducing modern educational projects in cooperation with representatives of business, government, and public organizations in the context of innovatization of the economy.

In order to achieve the educational goals of teaching master students the above mentioned elective courses, we have tested the following organizational forms of academic training: review, problem-based, and binary lectures (together with representatives of business, government, and public organizations of the region); interactive practical classes (creative work in educational and project groups, use of interactive methods and forms of education (the case method, auctions of creative ideas in the field of corporate social responsibility in an educational institution, problem-based discussions, business games, trainings, situational exercises with analysis of real cases of successful projects for the development of entrepreneurial activity of education managers, effective strategies of corporate social responsibility in educational institutions; group viewing of projects clusters [1] and videos of webinars [22] with their subsequent discussion;

independent work of students, namely: performing a set of individual tests, problem-based and creative tasks as well as studying scientific and methodical literature; full-time consultation (instruction), online consultation (instruction), joint selection in the design dyads of sets of printed and multimedia methodical sources for independent study; development in project mini-groups of strategies for introducing various areas of corporate social responsibility in pre-school, primary, out-ofschool, and alternative education institutions (preparing social reports and presentations to participate in a creativity competition of master students' projects).

For getting acquainted with successfully implemented strategies of corporate social responsibility in educational institutions and carrying out their educational analysis, future managers should independently consider their clusters posted on the websites of universities and various public organizations. Thus, for example, we have focused attention of masters on a cluster of social business projects initiated within the framework of the International Student Organizations SIFE (Students in Free Enterprise) [31], ENACTUS [11]. The social reports presented in the cluster reflect the results of social and business projects implemented in educational institutions. Such projects integrate the following aspects: ecology, school entrepreneurship, community liaison, charity, media liaison. For a joint discussion with students, there were chosen the following projects: Christmas Market (Republic of South Africa, People's Republic of China), a bookshop (Russia), the Leadership Academy, a school waste sorting center (South Korea), a school charity youth organization Step by Step (Brazil), the production of women's hats and jewelry (Nigeria), etc.

The set of individual and group research tasks for masters at a faculty of education, tested at Izmail State Humanitarian University to optimize the training of future managers to develop strategies for corporate social responsibility, includes the entire vector of preschool, primary, and out-of-school education $[4 ; 12 ; 19 ; 25]$. 
For the convenience of implementing methodological support for project mini-groups, an academic planner, which combines the main stages of preparing corporate social responsibility strategies in an educational institution, has been developed.

To analyze and select the most productive social reports of masters on the development of corporate social responsibility strategies in educational institutions, we used the following criteria:

1. Presence of a business plan of a new profitable project (masters demonstrate knowledge in the field of entrepreneurship and business, apply knowledge in practice, in order to plan and organize activities of their business in the field of education).

2. Inclusion in activities of an education manager of such components as: cooperation with entrepreneurs; import / export of products and services; study of the educational services market of countries leading in the field of education.

3. Awareness of importance of civic duty in a democratic society, its reflection in educational initiatives at the level of a municipality, district, region, country as a whole.

4. Positioning of an educational institution as an initiator of projects and programs for the purpose of environmental protection under conditions of a market economy.

5. Use of the assistance of partners in order to find and process the necessary information, evaluate and prepare a presentation of the corporate social responsibility strategy in an educational institution.

6. Cooperation with the business advisory commission (business representatives).

7. Use of mass media (articles in journals and newspapers, television, radio, Internet, business correspondence) in order to popularize ideas for developing a strategy of corporate social responsibility in an educational institution.

8. Presence of statistical indicators of the results of project activities (financial report, comparison of expected results with those obtained).

\section{CONCLUSION}

The recognition by the scientific and educational community of global challenges related to formal education of children and young people, the transformation of its monopoly due to the formation of alternative information segments of education and socialization of a person (in out-of-school centers, clubs, correspondence schools, network communities, etc.) has naturally led to rethinking modern approaches to professional development of competitive socially responsible managers in educational institutions.

Therefore, a priority aspect in the system of training masters in non-economic universities is the introduction of programs of elective courses aimed at developing the entrepreneurial competence of future leaders in the context of their independent development and implementation of corporate social responsibility strategies in educational institutions.
Testing a specially developed set of programs of elective courses at faculties of education allows future education managers mastering practices of introducing a wide variety of areas of the corporate social responsibility strategy (responsible practices in relation to teaching staff, environmental protection, fair business practices, responsible practices in relation to educational consumers) services, community development, charity, and volunteering).

\section{REFERENCES}

[1] A Guide to the Project Management Body of Knowledge (PMBOK ${ }^{\circledR}$ Guide) - Fifth Edition (2013). Pennsylvania, USA: Project Management Institute, 589.

[2] Belyaeva, I. Yu., Eskindarov, M. A. (2013). Korporativnaya sotsialnaya otvetstvennost: upravlencheskiy aspekt [Corporate social responsibility: managerial aspect]. Moscow, Russia: KNORUS, 245 (in Russ.)

[3] Bila, O. O. (2018). Sertyfikovana prohrama "Sotsialno-pedahohichne proektuvannia v zakladakh doshkilnoi ta pochatkovoi osvity" [Certified program "Social-pedagogical projectign in pre-school and elementary education institutions"]. Available at: http://idgu.edu.ua/wpcontent/uploads/2018/04/mah_sert_prohr_soc.-ped.-proektuvannja-1.pdf (in Ukr.)

[4] Bila, O. O. (2019). Sotsialno-pedagogichne proektuvannya v zakladah doshkilnoyi, pochatkovoyi ta pozashkilnoyi osviti (kontekst universitetskoyi pidgotovki sotsionomistiv) [Social-pedagogical projectign in institutions of pre-school, primary and extracurricular education (context of university preparation of socionomical)]. Odessa, Ukraine: Astroprint, 192 (in Ukr.)

[5] Bila, O. O. (2019). Robocha prohrama navchalnoi dystsypliny "Proektuvannia innovatsiinykh pedahohichnykh system u zakladakh doshkilnoi ta pochatkovoi osvity" [Work program of educational discipline "Projectign of innovative pedagogical systems in pre-school and primary education institutions"]. Available at: http://idgu.edu.ua/wpcontent/uploads/2019/02/proektuvannja-innovacijnyh-pedahohichnyhsystem.pdf (in Ukr.)

[6] Blagov, Y., Sobolev, I. (2014). Doklad o sotsialnyih investitsiyah v Rossii 2014: k sozdaniyu tsennosti dlya biznesa i obschestva [Report on social investments in Russia - 2014: creating value for business and society]. St. Petersburg, Russia: SPb, 144 (in Russ.)

[7] Burlayenko, T. I. (2011). Zmist i struktura ekonomichnoyi kompetentnosti maybutnih menedzheriv osviti yak neobhidna vimoga chasu [Content and structure of economic competence of future managers of education as a necessary requirement of time]. Teoriia ta metodyka upravlinnia osvitoiu - Theory and methodology of education management, 7, 10-15 (in Ukr.)

[8] Coleman, J. S. (1988). Social Capital in the Creation of Human Capital. American journal of sociology, 94, 95-120.

[9] Dmitriev, V. A. (2011). Korporativnaya sotsialnaya otvetstvennost. Novaya filosofiya biznesa [Corporate social responsibility. New business philosophy]. Moscow, Russia: Vneshekonombank, 56 (in Russ.)

[10] Donia, M. B. L., Tetrault Sirsly C. A. (2016). Determinants and consequences of employee attributions of corporate social responsibility as substantive or symbolic. European Management Journal, 34(3), 232242, DOI: $10.1016 /$ j.emj.2016.02.004

[11] ENACTUS in Ukraine. Available at: https://enactus.org.ua/proekti/

[12] Gatto, JohnTaylor. (2001). The underground history of American education: an intimate investigation into the prison of modern schooling. New York, USA: Oxford Village Press, 412.

[13] Gontareva, I., Murenets, I., Kurmaiev, P., Podzihun, S., Dorokhov, O. (2018). Functionality and quality management of transformation of capital forms at an enterprise. TEM Journal, Volume 7, Issue 3, 597-606, DOI: $10.18421 /$ TEM73-16.

[14] Gontareva, I. V. (2015). Struktura navchalnykh prohram pry formuvanni skladnykh kompetentnostei [Syllabus structure in the formation of complex competences]. Naukovyi Visnyk Natsionalnoho Hirnychoho 
Universytetu - Scientific Bulletin of National Mining University, 1, 127132 (in Ukr.)

[15] Gontareva I. V., Chorna Maryna, Pawliszczy Dariusz, Barna Marta, Osinska Oksana, Dorokhov O. (2018) Features of the entrepreneurship development in the digital economy. TEM Journal. Volume 7, Issue 4, Pages 813-822, DOI: 10.18421/TEM74-19.

[16] ISO $26000-$ Social responsibility (2010). Available at: https://www.iso.org/iso-26000-social-responsibility.html

[17] Kotler, P., Caslione, J. A. (2009). Chaotics: the business of managing and marketing in the age of turbulence. New York, USA: AMACOM, 224.

[18] Kotler, P., Lee, N. (2004). Corporate social responsibility: doing the most good for your company and your cause. New York, USA: John Wiley \& Sons, 320 .

[19] Kotter, J., Heskett, J. (1992). Corporate Culture and Performance. New York, USA: Free Press, 214.

[20] Larionova, M. V. (2005). Aktualnyie voprosyi razvitiya obrazovaniya $\mathrm{V}$ stranah OESR [Topical issues of the education development in OECD countries]. Moscow, Russia:GU VHE, 152 (in Russ.)

[21] MEMO/11/730 Corporate Social Responsibility: a new definition, a new agenda for action. (2011). Available at: http://europa.eu/rapid/pressrelease_MEMO-11-730_en.htm

[22] Panasenko, N. (2019). Psykholohichne pidgruntia rozvytku pidpryiemnytskoi kompetentnosti $\mathrm{v}$ uchniv starshykh klasiv: mify ta stereotypy [Psychological basis of entrepreneurial competence development in high school students: myths and stereotypes]. Available at: https://naurok.com.ua/uploads/webinar/67/presentation.pdf (in Ukr.)

[23] Panova, A. Yu. (2017). Sotsial'nyye investitsii rossiyskogo biznesa: dinamika i struktura [Social investments of Russian business: Dynamics and Structure]. Mezhdunarodnyiy nauchno-issledovatelskiy zhurnal International Research Journal, No. 04 (58), Issue 3, 112-117 (in Russ.)

[24] Perfilieva, O. V. (2011). Universitet i region: na puti k realizatsii tret'yey funktsii [University and a region: on the way to the implementation of the third function]. Vestnik mezhdunarodnyih organizatsiy: obrazovanie, nauka, novaya ekonomika - Bulletin of international organizations: education, science, new economy. Volume 6, No. 1, 133-144 (in Russ.)

[25] Polyakova, A. G. (2018). Integratsiya protsessov dualnogo obrazovaniya i korporativnoy sotsialnoy otvetstvennosti promyishlennoy kompanii
[Integration of processes of dual education and corporate social responsibility at an industrial company]. Upravlenets - The manager, Volume. 9, No. 2, 31-40, DOI: 10.29141/2218-5003-2018-9-2-6 (in Russ.).

[26] Porter, M., Kramer, M. (2006). Strategy and society: the link between competitive advantage and corporate social responsibility. Harvard Bisness Review. Available at: https://hbr.org/2006/12/strategy-andsociety-the-link-between-competitive-advantage-and-corporate-socialresponsibility.

[27] Ramazanov, S., Antoshkina, L., Babenko, V., Akhmedov, R. Integrated model of stochastic dynamics for control of a socio-ecological-oriented innovation economy (2019). Periodicals of Engineering and Natural Sciences, vol. 7 , no. 2, pp. 763-773. DOI: http://dx.doi.org/10.21533/pen.v7i2.557

[28] Robinson, K., Aronica, L. (2016). Creative schools: The grassroots revolution that's transforming education. New York, USA: Penguin Books; Reprint edition, 320.

[29] Shahnazaryan, B. A., Telnyh, V. S. (2016). Korporativnaya sotsialnaya otvetstvennost kak faktor konkurentnogo preimuschestva predpriyatiya [Corporate social responsibility as factor of competitive edge of enterprise]. Tavricheskiy nauchnyiy obozrevatel - Tavricheskiy Scientific Commentator, 1, 73-75 (in Russ.).

[30] Sheraysina, R.M., \& Donina, I.A. (2013). Stanovlenie i razvitie sovremennogo rukovoditelya obrazovatelnogo uchrezhdeniya [Formation and development of the modern head of the educational institution]. Vektor nauki Tolyattinskogo gosudarstvennogo universiteta. Seriya: Pedagogika, psihologiya - Science vector of Tolyatinskiy State University. Series: Pedagogy, Psychology, No. 2 (13), 309-312 (in Russ.).

[31] Students in Free Enterprise (SIFE). Available at: https://simple.wikipedia.org/wiki/Students in Free Enterprise

[32] World development report: DIGITAL DIVIDENDS. (2016) International Bank for Reconstruction and Development / The World Bank. URL. Available http://documents.worldbank.org/curated/en/896971468194972881/pdf/1 02725-PUB-Replacement-PUBLIC.pdf

\section{Creative Commons Attribution License 4.0 (Attribution 4.0 International, CC BY 4.0)}

This article is published under the terms of the Creative Commons Attribution License 4.0 https://creativecommons.org/licenses/by/4.0/deed.en US 